\title{
Petrology, mineral chemistry and thermobarometry of eclogite nodules from the Mbuji Mayi kimberlite, Kasai, Congo : significance of kyanite-cpx intergrowths
}

\author{
El Fadili, S. ${ }^{1}$, and Demaiffe, D. ${ }^{1}$
}

1. Univ. Libre de Bruxelles. Géochimie Isotopique (CP 160/02). 50. Av. Rooserelt. 1050. Bruxelles. Belgium.

The eclogite nodules have been sampled in the diamondiferous Mbuji Mayi kimberlites (Kasai, Congo) which intruded the Archean Congo-Kasai Craton $70 \mathrm{Ma}$ ago (Schärer et al., 1997). Beside the eclogites ( $>90 \%$ of the xenolith population), the kimberlites also contain crustal nodules and the typical megacryst suite (Cr-diopside, garnet, Mg-ilmenite, rutile and more exceptionnally large -up to $1 \mathrm{~cm}$ - zircon and baddeleyite).

This study is focused on high-grade nodules, especially eclogites and granulites.

The nodules have rounded to ellipsoidal shapes and typically range in size from 3 to $5 \mathrm{~cm}$, except two large eclogites up to $10 \mathrm{~cm}$.

Among the 152 studied nodules, four main groups have been distinguished petrographically:

1- typical bimineralic eclogites (109 samples) which consist mainly of garnet and omphacitic clinopyroxene together with one or two accessory phases like rutile, phlogopite, quartz, pargasite, zoisite and apatite.

2 - kyanite-bearing eclogites ( 39 samples) : the modal kyanite content varies considerably from 1 up to 25 $\%$. Kyanite occurs either as spectacular intergrowths with cpx (similar to those described by Griffin et al., 1979, in Lesotho xenoliths), as subhedral laths (locally included in garnet) or as large (3 mm) poikilitic grains including garnet and clinopyroxene.

3 - only one diamond-bearing eclogite has been observed : it has the highest modal garnet content (70\%). Microdiamonds (average size: $0.4 \mathrm{~mm}$ ) are grey to greyish white, often cubic (or twinned-cubes).

Diamonds included in garnet are generally rounded and transparent. Graphite blebs are present both at the surface and within the diamonds.

4- among the granulite nodules, 3 samples contain kyanite. When adjacent to diopside, plagioclase $\left(\mathrm{An}_{48}\right)$ breaks down progressively to produce kyanite-clinopyroxene intergrowths, similar to those observed in kyanite-bearing eclogites.

Most eclogites display granoblastic textures, with well-developed triple junctions $\left(120^{\circ}\right)$ between grains. Tightly interlocking textures and banded textures (average thickness of layers : $2 \mathrm{~mm}$ ) have been observed in some nodules. Diamond-bearing eclogite shows rounded to euhedral garnets set in an interstitial matrix of clinopyroxenes : this cumulate texture is similar to Roberts Victor group I eclogites (Mac Gregor and Carter, 1970).

Clinopyroxenes from bimineralic eclogites have uniformly high $\mathrm{Mg \#} \mathrm{(88-92)} \mathrm{with} \mathrm{variable} \mathrm{Jd} \mathrm{content} \mathrm{(19-}$ 40 moles \%). The kyanite-bearing and diamond-bearing eclogites have lower Mg\# (83-89 and 80 respectively) while the Jd content tends to be high (37-48 moles \% and 30 moles \%). In the $\mathrm{Na}_{2} \mathrm{O}-\mathrm{MgO}$ diagram (Fig. 1) of Taylor and Neal (1989), most cpx plot in field B, only 2 plot in field C. In some bimineralic eclogites, clinopyroxenes contain garnet (exsolution) lamellae. In the 3 eclogite groups, cpx sometimes shows a "spongy texture" which consists of symplectitic intergrowths of diopside and plagioclase $\left(\mathrm{An}_{8-17}\right)$.

$\mathrm{Cpx}$ of kyanite-bearing granulites is an $\mathrm{Al}_{2} \mathrm{O}_{3}$-rich (10 wt \%) diopside with very high $\mathrm{Mg \#} \mathrm{(94)} \mathrm{but} \mathrm{low} \mathrm{Jd}$ content (13 moles \%).

Garnet's composition falls in the field of other eclogitic garnets (Fig.2). Garnets from kyanite-bearing eclogites $(\mathrm{Mg \#}=43-63)$ are slightly more enriched in grossular and in alm+spess than those of bimineralic and diamond-bearing eclogites. Garnet from the diamond-bearing eclogite has the highest $\mathrm{Na}_{2} \mathrm{O}$ content $(0.18 \mathrm{wt} \%)$. In the samples containing garnet lamellae in cpx, it is common to find a rim of garnet grains (necklace texture) around cpx, suggesting outside migration (and recrystallisation) of the garnet lamellae from the cpx. This necklace texture coexists with spongy clinopyroxenes.

Garnets from kyanite-bearing granulites are similar to those of kyanite-bearing eclogites.

Rutile is the most common accessory phase in eclogite nodules; it appears either as primary crystals interstitial to garnet and clinopyroxene or as oriented needles (exsolutions ?) in garnet and omphacite. Quartz occurs as equant grains or as inclusions surrounded by radial cracks in omphacite and garnet. Coesite has been not found. Phlogopite is common in bimineralic eclogites, but is rare in kyanite-bearing 
varieties. "Primary" phlogopite (Mg\#=90-93) occurs as large euhedral flakes in the texture defined by cpx and garnet grains. Apatite occurs mostly as euhedral prisms or forms triple junctions $\left(120^{\circ}\right)$ with garnet and clinopyroxene, which suggests its primary origin. In one bimineralic eclogite, the phosphate mineral is whitlockite $\left(\mathrm{Ca}_{9} \mathrm{Mg}\left(\mathrm{PO}_{3} \mathrm{OH}\right)\left(\mathrm{PO}_{4}\right)_{6}\right)$ instead of apatite.

Pargasitic amphibole (Mg\#= $89, \mathrm{~K}_{2} \mathrm{O}=1.26 \mathrm{wt} \%$ ) and zoisite are rare.

Mbuji Mayi eclogites have been variously affected by metasomatic events. This is marked either by numerous thin $(100 \mu \mathrm{m})$ veins cross-cutting the nodules and consisting mainly of phlog+amph+apat+zois or by secondary minerals which develop at the margins of the nodules (contact with the host kimberlites) and around primary minerals. "Secondary" phlogopite is distinctly more Fe-rich $(\mathrm{Mg} \#=79-86)$ than "primary" phlogopite; it occurs mainly around garnet grains and in the veins. Pargasite sometimes forms large rims around both cpx and garnet or occurs as fibrous material along grain boundaries. Metasomatic pargasite typically has lower Mg\# (65-69) and lower $\mathrm{K}_{2} \mathrm{O}$ content $(<0.18$ wt \%) than the primary amphibole. Anhedral apatite locally appears at the rims of the nodule or in the veins. Zoisite often occurs as large anhedral crystals around clinopyroxene and sometimes in the veins. Rutile also forms rounded grains at the margins of the nodule : this metasomatic rutile is strongly enriched in $\mathrm{Nb}$ (up to $9 \% \mathrm{Nb}_{2} \mathrm{O}_{5}$ ) and is similar to that reported by Haggerty (1983) in Jagersfontein kimberlites.

Some nodules show evident signs of partial melting : patches of brown glass corroding the main minerals (cpx, garnet and phlogopite) are quite common; this glass is partly devitrified and contains small $(50 \mu \mathrm{m})$ euhedral plagioclase laths with minor zoisite. Locally, the same brown glass also occurs in the spongy texture of the $\mathrm{cpx}$.

Equilibration $\mathrm{T}^{\circ}$ have been estimated from the Fe-Mg partitioning between garnet and clinopyroxene. The calibration of Ellis and Green (1979) gives, at an assumed pressure of $30 \mathrm{~kb}$ for bimineralic and kyanite eclogites and $50 \mathrm{~kb}$ for the diamond-bearing sample, temperatures between 815 and $1260{ }^{\circ} \mathrm{C}^{\left(\mathrm{Fe}^{2+}\right.}$ content has been obtained following the procedure of Clarke and Papike, 1968). Application of the revised calibration ( $\mathrm{Ai}, 1994)$ gives significantly lower $\mathrm{T}^{\circ}$ than Ellis and Green calibration (100 to $200{ }^{\circ} \mathrm{C}$ lower). Direct pressure estimates for most eclogites are not possible because the lack of calibrated geobarometer for the garnet-omphacite pair. Minimun pressure for quartz-bearing eclogites using the $\mathrm{Ab}->\mathrm{Jd}+\mathrm{Qz}$ calibration (Holland, 1980) ranges between 17 to $20 \mathrm{~kb}$; the lack of coesite constrains the maximum pressure to be less than $27-29 \mathrm{~kb}$. P estimates for kyanite-bearing eclogites may be obtained from the CaAl partition between garnet and clinopyroxene (Banno, 1974; Lappin, 1978) : the Mbuji Mayi kyanite eclogites were equilibrated at about 20 to $25 \mathrm{~kb}$. The presence of diamond in one sample allows, by using the diamond-graphite curve of Kennedy and Kennedy (1977), to estimate the equilibration pressure at 52 $\mathrm{kb}$, for $1260{ }^{\circ} \mathrm{C}$. Rough pressure estimates for the other bimineralic eclogites can be obtained by plotting the calculated temperatures along the Precambrian shield geotherm $\left(40 \mathrm{~mW} / \mathrm{m}^{2}\right)$ of Pollack and Chapman (1977) or along the Finnerty and Boyd's geotherm (1986): P ranges from 34 to $50 \mathrm{~kb}$. The equilibration pressure for kyanite-bearing granulites using the $\mathrm{An}->\mathrm{Ga}+\mathrm{Qz}+\mathrm{Ky}$ calibration (Koziol and Newton, 1988) is $20 \mathrm{~kb}$ at $913^{\circ} \mathrm{C}\left(\mathrm{T}^{\circ}\right.$ from cpx-ga pair).

The origin of peraluminous (i.e. kyanite- or corundum-bearing) eclogites has been and is still debated. The data obtained on Mbuji Mayi eclogite and granulite nodules can shed some light on this problem. Detailled petrographic observations of the granulites unequivocally show that the cpx-kyanite intergrowths, together with the associated garnet and quartz, result from the breakdown of the original plagioclase reacting with aluminous diopside during a prograde high $P$ event.

In the eclogites, primary plagioclase is completely lacking and the symplectites are interpreted as the complete breakdown of former plagioclase. We thus suggest that the nodules were sampled by the Mbuji Mayi kimberlites from the diamond stability field to the uppermost mantle and lower crust, across the granulite/eclogite transition. The protoliths of the kyanite-bearing eclogites are thus probably plagioclaserich rocks (gabbros, anorthosites). This conclusion is confirmed by available geochemical data : high $\mathrm{Al}_{2} \mathrm{O}_{3}$ (up to 28 wt \%) and $\mathrm{CaO}$ (up to 15 wt \%) contents associated with high positive $\mathrm{Eu}, \mathrm{Ba}, \mathrm{Pb}$ and $\mathrm{Sr}$ anomalies in spidergrams (see Demaiffe et al., this volume). 


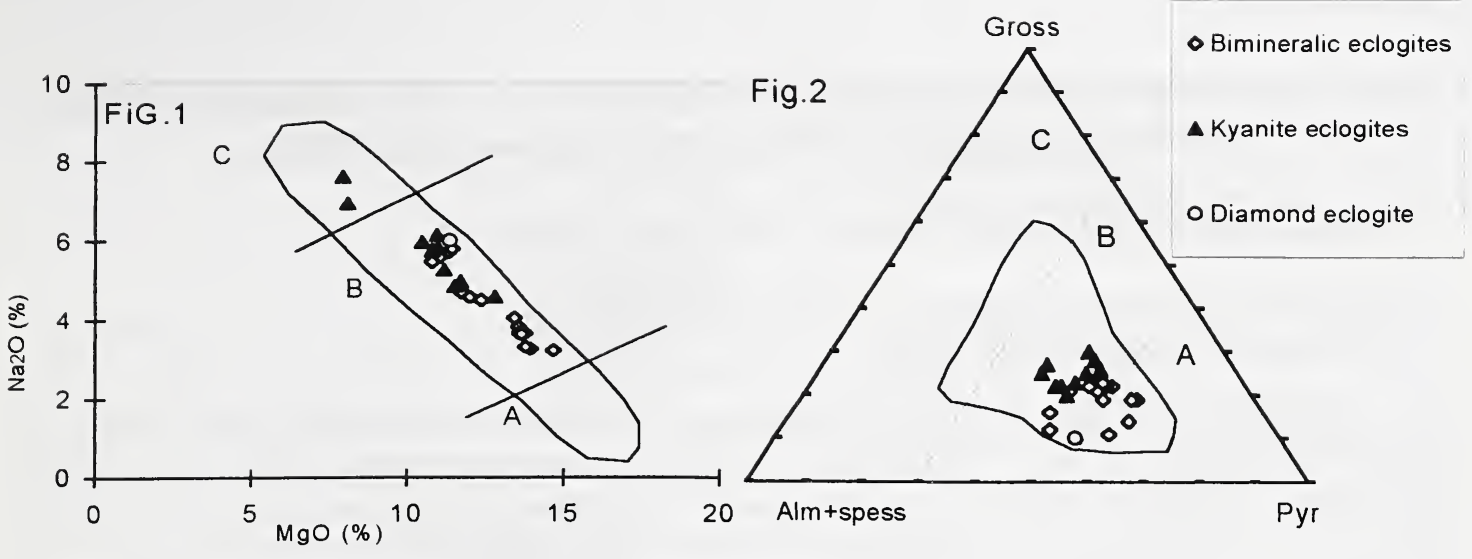

Fig. 1. $\mathrm{Na}_{2} \mathrm{O}-\mathrm{MgO}$ diagram of Taylor and Neal (1989) for eclogitic clinopyroxenes.

Fig.2. Gross-Alm+Spess-Pyr diagram of Coleman et al. (1965) for eclogitic garnets. Fields correspond to the compilation of data from Taylor and Neal (1989), Sobolev et al. (1994), Snyder et al. (1997).

\section{References}

$\mathrm{Ai}, \mathrm{Y}$., 1994, A revision of the garnet-clinopyroxene Fe2+-Mg exchange geothermometer: Contrib. Mineral. Petrol., 115, p. 467-473

Banno, S., 1974, Use of partial solution of multi-component equilibria. Case study of pyroxene-bearing assemblages: Bull. Soc. Franc. Minéral. Cryst., 97, p. 108-116.

Coleman, R.G., Lee, D.E, Beatty, L.B., and Brannock, W.W., 1965, Eclogites and eclogites: their differences and similarities : Geol. Soc. Am. Bul., 76, 483-508

Ellis, D. J. and Green, D. H., 1979, An experimental study of the effect of Ca upon garnet-clinopyroxene Fe-Mg exchange equilibria: Contrib. Mineral. Petrol., 71, 13-22.

Finnerty, A.A. and Boyd, F.R., 1987, Thermobarometry for garnet peridotites: basis for the determination of thermal and compositional strucure of the upper mantle: in Mantle xenoliths (Nixon, P.H. editor), p. $381-402$.

Griffin, W.L., Carswell, D.A., and Nixon, P.H., 1979, Lower crustal granulites and eclogites from Lesotho, South Africa, In the mantle sample : Inclusions in kimberlites and their other volcanics, Proceedings of the 2th Intern. Kimberl. Conf., vol.2, (F.R. Boyd and H.O.A. Meyer editors), p. 59-86.

Haggerty, S. E., 1983, The mineral chemistry of new titanates from the Jagersfontein kimberlite, South Africa: implications for metasomatism in the upper mantle : Geochim. Cosmochim Acta, 47, p. 1833-1854 Holland, T.J.B., 1980, The reaction albite-jadeite+quartz determined experimentally in the range 600$1200^{\circ} \mathrm{C}$ : Amer. Mineral., 65, p. 129-134.

Jerde, E.A., Taylor, L.A., Crozaz, G.C., Sobolev, N.V., and Sobolev, V.N., 1993, Diamondiferous eclogites from Yakutia, Siberia : Evidence for a diversity of protoliths: Contrib. Mineral. Petrol., 114, p. 189-202.

Kosiol. A.M. and Newton, R.C., 1988, Redetermination of the anorthite breakdown reaction and improvement of the plagioclase-garnet- $\mathrm{Al}_{2} \mathrm{SiO}_{5}$-quartz geobarometer: Amer. Mineral., 73, p. 216-233

Lappin, M.A., 1978, The evolution of a grospydite from Roberts Victor Mine, South Africa: Contrib. Mineral. Petrol., 66, p. 229-241.

Mc Gregor, I. D. and Carter, J.L., 1970, The chemistry of clinopyroxenes and garnets from eclogite and peridotite xenoliths from the Roberts Victor Mine, South Africa: Phys. Earth Planet. Inter., 3, p. 391-397. Pollack, H.N. and Chapman, D.S., 1977, On the regional variation of heat flow, geotherms, and lithospheric thickness: Tectonophysics, 38, 279-296.

Schärer, U., Corfu, F., and Demaiffe, D., 1997, U-Pb and Lu-Hf isotopes in baddeleyite and zircon megacrysts from the Mbuji Mayi kimberlite: constraints on the subcontinental mantle: Chem. Geol., 143, p. $1-16$.

Snyder, G.A., Taylor, L.A., Crozaz, G.C., Halliday, A.N., Beard, B.L., Sobolev, N.V., and Sobolev, V.N., 1997, The origins of Yakutian eclogite xenoliths: J. Petrol., 38, 85-113.

Sobolev, V.N., Taylor, L.A., Snyder, G.A., and Sobolev, N.V., 1994, Diamondiferous eclogites from the Udachnaya kimberlite pipe, Yakutia: Int. Geol. Rev., 36, p. $42-64$.

Taylor, L.A., and Neal, C.R. J., 1989, Eclogites with oceanic crustal and mantle signatures from the Bellsbank kimberlite, South Africa, Part I: Mineralogy, petrography and whole rock chemistry: J. Geol., 97, p. 551-567. 